\title{
High-resolution signatures of oxygenation and microbiological activity in speleothem fluid inclusions
}

\author{
Nigel J.F. Blamey ${ }^{1,2^{*}}$, Penelope J. Boston ${ }^{1,3}$, and Laura Rosales-Lagarde ${ }^{1,3,4}$ \\ ${ }^{1}$ Department of Earth and Environmental Science, New Mexico Tech, Socorro, NM 87801, USA \\ ${ }^{2}$ Department of Earth Sciences, Brock University, St Catharines, ON, L2S 3A1, Canada \\ ${ }^{3}$ National Cave and Karst Research Institute, Carlsbad, NM, 87222 USA \\ ${ }^{4}$ Department of Physical \& Life Sciences, Nevada State College, Henderson, NV 89002 USA
}

\begin{abstract}
Speleothems frequently host "fossil" fluids that were trapped in small inclusions during growth. Such fluids may provide valuable clues to past microbial, geochemical, and climatic processes during their formation. However, one difficulty is to understand which gases represent background atmosphere and fluids within a given cave system at a particular time, and which may be the product of post-trapping residual microbial activity or abiotic chemical reactions? Do we have any hope of sorting out these differences? The success depends on a quantitative understanding of the gas composition trapped in the inclusions and an understanding of the interactions of cave mineralogy, air and water chemistry, and microbiological processes that may interfere with climatic or geochemical interpretations. Our proof-of-concept project uses time synchronous samples from several sites. We report here on this pilot investigation of speleothem inclusions using a methodology for quantitatively analyzing gases dissolved in inclusion fluids. We use incremental crushing of highly spatially resolved samples by mass spectrometry. Here, we report primarily on $\mathrm{CH}_{4}, \mathrm{CO}_{2}, \mathrm{O}_{2}$, and $\mathrm{N}_{2}$, but have included other detectable gases. The detection limit for $\mathrm{He}$ within aqueous fluid inclusions is $\sim 0.2 \mathrm{ppm}$ and gas ratios have $\sim 5 \%$ precision using natural standards. We used chemically inert argon as a tracer gas to normalize results to air or air-saturated water. This enables interpretation of gas data despite variability in hydrological and geological cave histories. Results are variable. For example, in one case oxygen was depleted while nitrogen was increased, which may be attributable to the breakdown of nitrate or nitrogen-containing biomolecules. In other cases, oxygen is enriched which may be attributed to several factors both geochemical and biological. We suggest potential interpretations between the competing hypotheses with larger future data sets. This first attempt tackles the complex and intertwined speleological questions using the inclusion gas method.
\end{abstract}

Keywords: fluid inclusions, fluid inclusion gases, microbial activity, speleothems

Received 25 August 2015; Revised 15 August 2016; Accepted 16 August 2016

Citation: Blamey N.J.F., Boston P.J. and Rosales-Lagarde L., 2016. High-resolution signatures of oxygenation and microbiological activity in speleothem fluid inclusions. International Journal of Speleology, 45 (3), 231-241. Tampa, FL (USA) ISSN 0392-6672

http://dx.doi.org/10.5038/1827-806X.45.3.1950

\section{INTRODUCTION}

Speleothems are secondary mineral deposits that form in subterranean voids (caves, vugs, and mines). They are produced by processes ranging from deposition of minerals from saturated waters (Palmer, 2007) to bedrock breakdown and reprecipitation by microbial processes (Boston et al., 2009). Chemical, physical, and biological conditions can range from highly variable in caves with active streams or high ventilation conditions to very stable over considerably longer periods of time in certain cave systems. The latter highly stable situation would be the case where speleothems have been influenced by hydrologically quiescent systems, especially where water and atmospheric composition are relatively sealed away from surface influences.

In the broad sense, fluid inclusions are microscopic cavities within rocks and minerals that comprise any combination of liquid, solid and/or gas (Roedder, 1984). These fluid inclusions develop during mineral growth or by annealing of secondary fractures and trap the actual fluids, gases, and other compounds that were once present in the greater environment. As 
carbonates (and some other minerals) are deposited in caves, they develop small inhomogeneities that result in such inclusions. These can act as micron scale chemical and microbiological time capsules, and can be used to help us examine changes in system condition, by providing portals into former microbial communities and past climate conditions that once occurred in the caves. Besides fluid, both dissolved salts and gases are often typically present. Some inclusions may also contain organic material that has been shown to be useful as a climate signal (e.g., Baudin et al., 2007), and trapped microorganisms that are still alive yielding analyzable DNA (Boston, unpub. results).

Gases trapped in cave speleothems are analogous to several other types of data. For example, ice cores in polar regions trapped fossil atmosphere in snow, and are now used as a standard approach to understanding ancient atmospheres (e.g., EPICA, 2004). Carbon-dioxide and other gases remain trapped in bubbles within the ice and it is assumed that the gas concentrations have not been modified since entrapment, but this may or may not be a legitimate supposition if microbial or geochemical processes alter the abundance of $\mathrm{CO}_{2}$ within the bubbles. The gas concentrations are analyzed by mass spectrometry and the data is correlated with other data [e.g., ice $\delta \mathrm{D}$ and $\delta^{18} \mathrm{O}$ ]. These are used to build models of climatic change. This method of evaluating such trapped gases is applicable to polar and boreal conditions, and tropical glacial examples (e.g., from the Andes) have been advanced to explain tropical climate change (e.g., Ginot et al., 2002). However, our understanding of possible atmospheric conditions in the mid-latitude regions where human populations and vegetation are highly concentrated must be based on additional analytical techniques. Caves offer the potential for mid-continental and low latitude paleoclimate proxies (e.g., Martin \& White, 2008; Lachniet, 2009). Although the emphasis has been on what these sites can tell us about climate, the potential for microbial processes to interfere with such interpretations by altering either the concentration of gases, transforming gases into other materials as consequences of metabolism, or altering isotopic ratios has been largely ignored. We believe that this must be investigated in order to validate ongoing studies and to uncover any potential pitfalls that might compromise such datasets and climate interpretations.

Fluid inclusions in speleothems were originally studied 30 years ago (Schwarcz et al., 1976) but are recently being regarded anew as valuable paleoclimate proxies, with most work concentrated on the stable isotope composition of water in inclusions (Matthews et al., 2000; Dennis et al., 2001; Fleitmann et al., 2003; Serefiddin et al., 2005; van Breukelen et al., 2008; Verheyden et al., 2008; Dublyansky \& Spotl, 2009). Some research has focused on noble gas concentrations (Kluge et al., 2008; Scheidegger et al., 2010). Prior research has shown that $\delta^{13} \mathrm{C}$ and $\delta^{18} \mathrm{O}$ stable isotopes reflect changes through time using the
$\mathrm{U}-\mathrm{Th}-\mathrm{Pb}$ dating methods to constrain temporal variability (Brook et al., 2006; Dennis et al., 2001; Genty et al., 2002; McDermott, 2004). The potential for detecting radiatively active trace gases (RATG) of biological origin that are dissolved in inclusions has not previously been attempted, but the close coupling of the global biota to the climate system is a topic of intense interest (Arneth et al., 2010). Any approach that might aid interpretation of past instantiations of the Critical Zone would be immensely valuable in interpreting Earth's past biogeochemical state (NSF, 2011; Nordt et al., 2012).

Analyzing fluid inclusion composition is routinely performed by microthermometry as a first pass method (Shepherd et al., 1991). However, dissolved gases that cannot be detected at low concentration using microthermometry include several of particular interest to understanding microbiological processes (e.g., $\mathrm{CH}_{4}, \mathrm{~N}_{2}$ and other $\mathrm{N}$ species, $\mathrm{O}_{2}, \mathrm{CO}_{2}$, and low-mass organics). The alternative is to conduct quantitative fluid inclusion gas analysis by mass spectrometry, which is the approach used in studies of geothermal systems (Moore et al., 2001; Blamey, 2012; Blamey et al., 2015), hydrothermal ore deposits (Blamey, 2012), metamorphic fluids (Wright et al., 2012), and exotic materials relating to space exploration (Parnell et al., 2011; McMahon et al., 2012; Blamey et al., 2015), and diagenetic carbonates (Azmy \& Blamey, 2013).

In general, the solubility of calcium carbonate is controlled by several factors that include concentrations of calcium and bicarbonate ions, $\mathrm{CO}_{2}$ loss or gain, water loss or gain, $\mathrm{pH}$ changes, ionic strength changes of the fluid, and temperature. The solubility of calcite may be summarized by the following simple equation:

$$
\mathrm{Ca}^{2+}+2 \mathrm{HCO}_{3}^{-}=\mathrm{CaCO}_{3}+\mathrm{H}_{2} \mathrm{O}+\mathrm{CO}_{2}
$$

As simple as this equation may be, in the speleothem environment, several factors may influence and complicate this straightforward reaction. These factors include relative humidity or saturation, $\mathrm{CO}_{2}$ levels including microbially induced changes, local $\mathrm{pH}$, temperature, fluctuations of calcium and bicarbonate ions, and finally changes in the fluid ionic strength. Isolating the relative contribution of each factor that may control the speleothem growth may be very difficult, however, trapped fluids and gases may help to unravel such influences.

The physical conditions in the cave environment also affect the chemistry of the gas composition and concentration. For example, even in caves with nearly saturated humidity, evaporation still occurs. We see evidence of this in the presence of efflorescent cave minerals like magnesium sulfate (Hill \& Forti, 1997) that come and go with season, and bedrock breakdown products that have an evaporative mechanism as well as microbial and chemical degradative processes (e.g., moonmilk, cf. Curry et al., 2009). Thus, evaporatively driven processes contribute to the movement of materials through the 
system that further enhances deposition and in some cases also facilitates the breakdown of bedrock (Boston et al., 2001).

We offer the results of this preliminary study, although from a limited dataset, as a promising proof of concept of both the application of a method and as a first attempt to deconvolve the multifarious processes that no doubt occur in fluid inclusions. We believe that the techniques used can be employed to begin to tackle some very knotty issues with the interpretation of ancient and modern subsurface environments and associated climate parameters that are already being deduced from speleothem climate studies (e.g., Wong \& Breecker, 2015). Part of the challenge in interpretation comes because there are major heterogeneities that are occurring on very fine spatial scales. Of particular note, the incorporation of gases must reflect the atmospheric composition within subsurface cavities at various spatial resolutions which may not be homogeneous. Additionally, such incorporation could be influenced by microbial transformations at similar spatial scales both prior to capture within the mineral and as a result of residual biological activity after entrapment.

\section{Sample Descriptions}

We have opportunistically selected several sample types from significantly different cave environments that we have already been studying in other ways. These sites include deep, ancient carbonate caves in the high Guadalupe Mountains in New Mexico, a sulfuric acid-rich system and a conventional carbonate system in Mexico, and amorphous opal speleothems in granite caves in northern Spain (Fig. 1). We selected these to provide a range of very different environmental conditions during the formation period of the speleothems in order to see if we could understand the results and if the methodology was worth pursuing. We emphasize that this is a pilot effort piggy-backing on other funded studies, thus the selection of materials was constrained by this circumstance, but was optimized within those limits to provide a suite of very different cave environments.

Sampling methods are very simple since the contents of interest are tiny microbubbles within crystalline or amorphous mineral structures, and consist simply of selecting pieces of such material from speleothems of several sorts. Our methodology requires only minute pieces (sub-millimeter in diameter). In this pilot study, we do not have data on the age of the particular speleothems chosen although in several cases there is very minimal dating that partially constrains timescales. Further, we did not attempt to match morphological speleothem type from cave to cave because the caves are so different in fundamental lithologies and in speleogenetic processes that formed them and their speleothems that simple morphological similarity is irrelevant. We chose specimens that were the apparent product of interesting geochemical and environmental juxtapositions.

New Mexico: Endless Cave, McKittrick Hill, New Mexico, USA (Fig. 2), a now-dry fossil cave
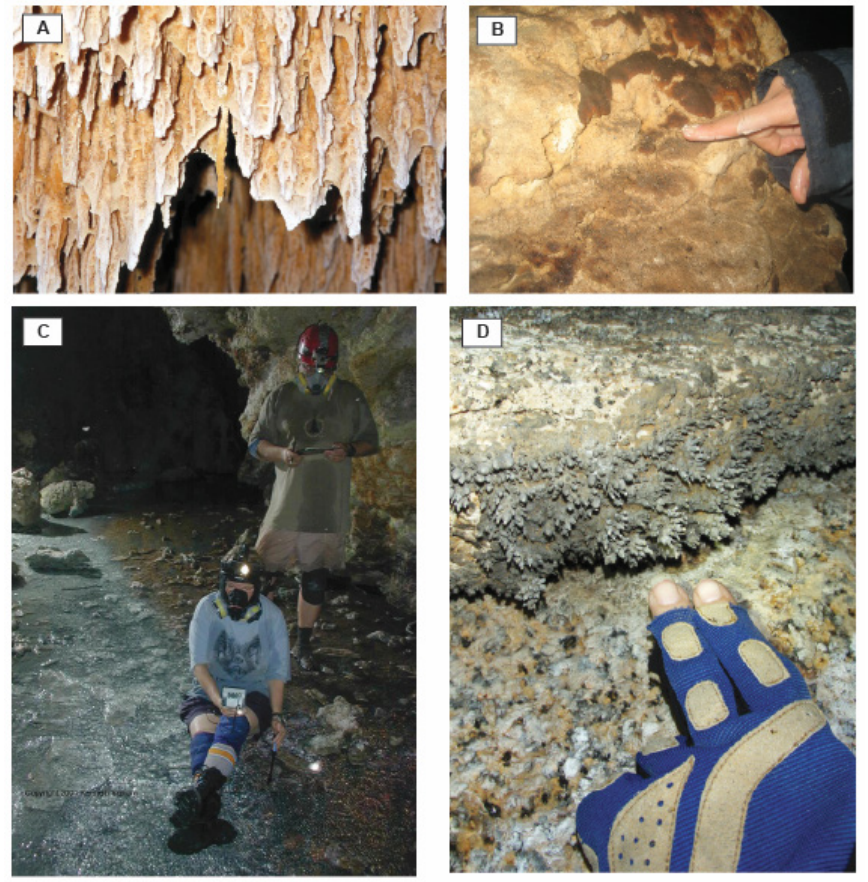

Fig. 1. Illustrations from the cave sites in this study. A. Endless Cave, New Mexico, a carbonate system with paleopool speleothems. B. Arroyo Azul Cave, Tabasco, Mexico, a carbonate system containing conventional stalagmites and flowstone (Image courtesy of JuanPablo Bernal). C. Cueva de Villa Luz, Tabasco, Mexico, an active sulfuric acid saturated cave. The Red and White Stream illustrated shows the sharp separation of waters of distinctive characteristics coming from separate springs within the cave. Low oxygen, high hydrogen sulfide waters are on the left, and low sulfide high oxygen waters are on the right (Rosales-Lagarde et al., 2014; Image courtesy of Kenneth Ingham). D. O Folón Cave, Gallicia, Spain. Clusters of small opal speleothems decorate the walls of these granite caves.

with extensive speleothem decorations that show evidence of microbiological activity (e.g., microfossils, micritic textures, and light carbon isotopic signals). Poolfingers (i.e. pendant carbonate structures that formed below the water level) show strong influences of microbial processes in geographically related caves (Melim et al., 2001, 2009).

Mexico: Mexican samples include: 1) a conventional appearing stalagmite (PAA-07) from Arroyo Azul Cave, Poana, Mexico; and 2) a carbonate concretion "cave pearl" (labeled Red Stream) from Cueva de Villa Luz, Tabasco, Mexico (Fig. 2). The Poana cave is a small cave system unaffected by any apparent unusual chemistry including no sign of sulfur influence, and the sample was deposited in a subaerial setting but has subsequently suffered some corrosion. In contrast, Cueva de Villa Luz is a sulfuric acid rich cave with a shallow stream flowing through it. A microbial role in many Villa Luz speleothems has been established (Hose et al., 2000; Boston et al., 2006; Rosales-Lagarde, 2012). The cave pearl was subsampled to try to establish whether different visually distinct layers within it had different characteristics. Additionally, a control sample from unaltered bedrock in the same cave was analyzed.

Spain: Grey opal-A speleothems on the $\mathrm{cm}$ scale were collected from O Folón Cave in northern Spain (Galicia). No further locational information is allowable under the collection agreements that allowed us access 


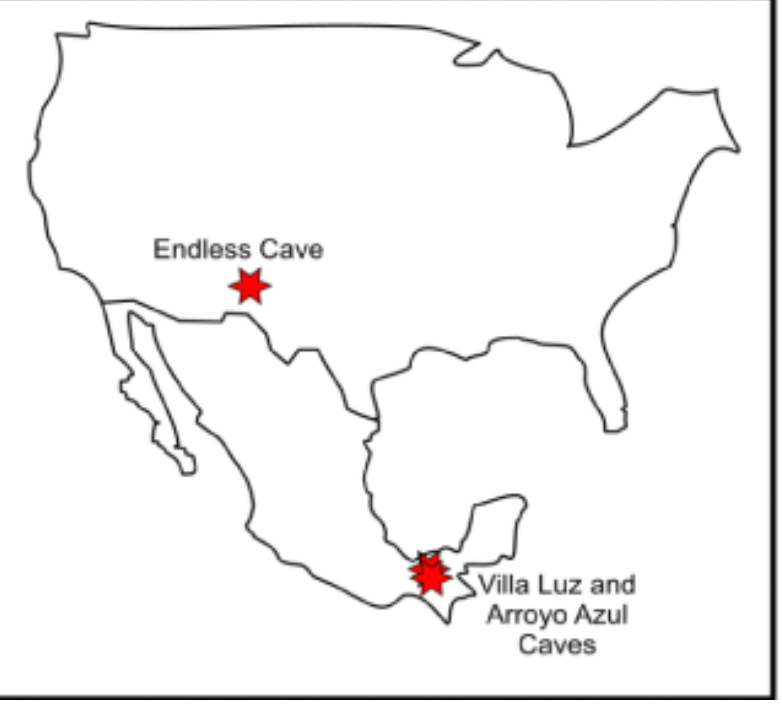

Fig. 2. General locality map for Endless Cave (New Mexico, USA), and the Villa Luz and Arroyo Azul caves in Mexico.

to that cave system. Granite caves are formed in large granitic plutons that intruded into the country rock approximately 350 million years ago. A plate collision during the Tertiary period caused the uplift and subsequent erosion of overlying strata, thus exposing the granite and allowing the subsequent development of the caves. The overlying rock mass eroded away exposing the granite, and elastically decompressing it producing unusual interior spallation of the granite (Vidal-Romani \& Vaqueiro-Rodriguez, 2007). The dense microbial mats that cover the insides of the caves greatly alter the $\mathrm{pH}$ of the fluids that condense on the cave walls greatly affecting the development of speleothems (Vidal-Romani et al., 2010 a, b) and we hypothesize that it may be a significant geochemical influence on inclusions as well.

\section{METHODOLOGY}

Fluid inclusion volatile analysis was done in vacuum using the CFS (crush-fast scan) method (Norman \& Moore, 1997; Norman \& Blamey, 2001; Blamey, 2012; Blamey et al., 2015) at New Mexico Tech's Fluid Inclusion Gas laboratory. Samples were first cleaned with $\mathrm{NaOH}$ to reduce surface organic contamination, and then were rinsed with deionized water, followed by drying at room temperature. Approximately 0.1 gram of material from the New Mexico and Mexico sites, and $\sim 30 \mathrm{mg}$ of sample from the Spanish opal speleothems were incrementally crushed under a vacuum of $\sim 10^{-8}$ Torr yielding two to ten crushes per sample. The analyses were performed by means of two Pfeiffer Prisma quadrupole mass spectrometers operating in fast-scan, peak-hopping mode. The system routinely analyzes for the following gaseous species: $\mathrm{H}_{2}, \mathrm{He}$, $\mathrm{CH}_{4}, \mathrm{H}_{2} \mathrm{O}, \mathrm{N}_{2}, \mathrm{O}_{2}, \mathrm{Ar}, \mathrm{CO}_{2}, \mathrm{SO}_{2}, \mathrm{C}_{2} \mathrm{H}_{4}, \mathrm{C}_{2} \mathrm{H}_{6}, \mathrm{C}_{3} \mathrm{H}_{6}, \mathrm{C}_{3} \mathrm{H}_{8}$, $\mathrm{C}_{4} \mathrm{H}_{8}, \mathrm{C}_{4} \mathrm{H}_{10}$, and benzene. The concentration of each gas specie was calculated by matrix inversion and multiplication (described in Blamey et al., 2015) to provide a quantitative analysis. The instrument was calibrated using commercial gas mixtures, synthetic inclusions filled with gas mixtures, and three in-house fluid inclusion gas standards as described by Norman and Blamey (2001) and Blamey et al. (2015).

Precision for this method is better than 5\% for major gaseous species and $0.2 \%$ for water/gas ratios using natural aqueous fluid inclusion standards (Norman $\&$ Blamey, 2001). These values are considered realistic for natural inclusions owing to an inherent variability between inclusions even in the same sample. In contrast, synthetic capillary tubes filled at $\sim 1$ mbar of atmospheric pressure gave a 1-sigma error of $0.5 \%$ for $\mathrm{N}_{2} /$ Ar ratios, which reflects ideal conditions (Blamey, 2012). The detection limit varies for most species and is dependent on burst size (i.e. inclusion gas yield), interference from other species, and instrument alignment (Blamey et al., 2015). However, it is calculated at $\sim 0.2 \mathrm{ppm}$ for inorganic species and 1-5 ppm for most organics, applying the formulae of Blamey et al. (2012, 2015).

\section{RESULTS}

All fluid inclusion gas analysis numerical data for non-aqueous inorganic species are presented in Table 1. A graphical representation of some of the key data is seen in Fig. 3. In the majority of analyses, water comprises $>99$ mole $\%$, however, we are focusing on the inorganic species and therefore report the nonaqueous key species. The dominant dissolved gases are $\mathrm{N}_{2}, \mathrm{CO}_{2}$, and $\mathrm{O}_{2}$ with minor concentrations of argon as well as $\mathrm{CH}_{4}$ and other organic compounds. Since argon is essentially inert and its presence is unaffected by biological activity except under extraordinary circumstances of very high pressures (e.g., Abraini et al. 1998), the gas ratios of $\mathrm{N}_{2} /$ Ar and $\mathrm{O}_{2} / \mathrm{Ar}$ may be valuable in recognizing variations in gases that are affected by biological activity. Additionally, Ar can also act as a normalizing, unreactive gas specie for geochemical interactions as well.

\section{New Mexico}

Endless Cave, NM, USA - The poolfinger sample has oxygen levels that are slightly below air-saturated water (ASW) and the $\mathrm{N}_{2} / \mathrm{Ar}$ ratios are between ASW and atmosphere (Fig. 3A). However, the trend for these samples seen in the same figure indicates that oxygen depletion correlates with $\mathrm{N}_{2}$ /Ar increase. Additionally, poolfingers have the lowest helium content of all the samples (Fig. 3B) and are in close agreement with atmospheric values. Further, the poolfingers have the lowest $\mathrm{CH}_{4}$ of all the samples (Fig. 3C). A single stalagmite sample from the same cave measured by V. Polyak (University of New Mexico) yielded a U-series age of $\sim 0.5 \mathrm{Ma}$ (pers. comm., 2013) using the methods reported in Polyak et al. (2004).

\section{Mexico}

Arroyo Azul Cave, Poana, Tabasco, Mexico - The conventional carbonate stalagmite sample (PAA07) has higher oxygen levels than either ASW or air (Fig. 3A). In addition, oxygen increase correlates with a decrease in $\mathrm{N}_{2} / \mathrm{Ar}$ ratio (Fig. 3A). PAA-07 is the most helium rich of all samples examined 
Carbonate Samples Silicate Samples

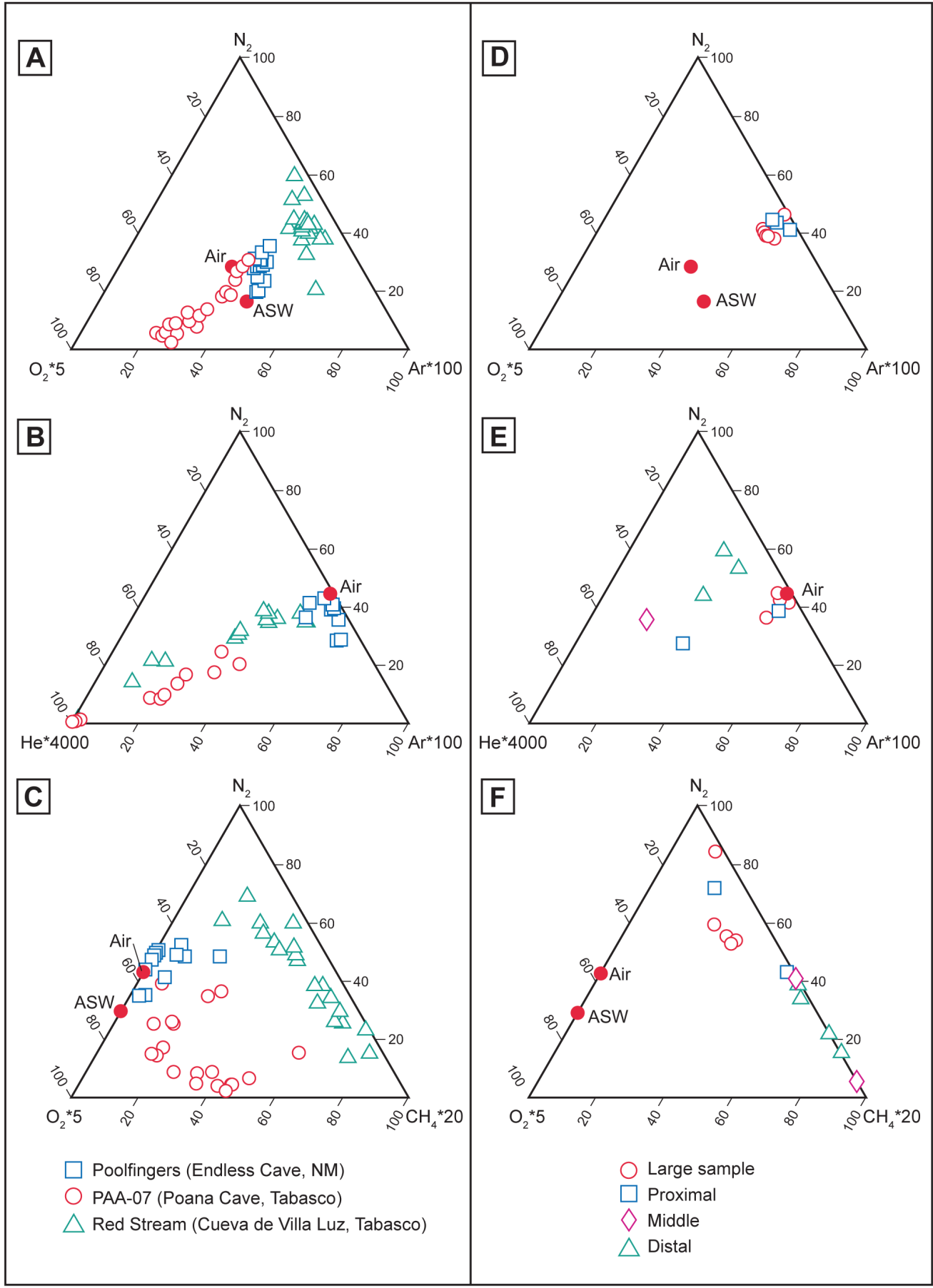

Fig. 3. Ternary plot comparisons of all studied gases. A. Ternary plot of $\mathrm{O}_{2}-\mathrm{N}_{2}-\mathrm{Ar}$ in carbonate samples. The Red Stream Pebbles are oxygen depleted and the $\mathrm{N}_{2} / \mathrm{Ar}$ spread may indicate nitrogen release due to protein breakdown. Poolfingers are slightly oxygen depleted whereas the PAA-07 samples are mostly enriched in oxygen that exceeds air-saturated water. Atmospheric gas ratios are labeled as "air" whereas "ASW" represents air-saturated water, the equivalent of water in equilibrium with the atmosphere; B. Ternary plot of $\mathrm{He}-\mathrm{N}_{2}-\mathrm{Ar}$ in carbonate samples. The poolfinger samples are the most helium depleted with helium concentrations close to atmospheric values. The Red Stream pebbles have higher helium contents whereas the highest helium is measured in PAA-07; C. Ternary plot of $\mathrm{O}_{2}-\mathrm{N}_{2}-\mathrm{CH}_{4}$ in carbonate samples. The poolfinger samples are the least methane rich whereas the Red Stream samples are oxygen depleted. Each sample plots in separate fields of the diagram indicating that the environments in which they form are distinctly different (Rosales-Lagarde, 2012; Rosales-Lagarde et al., 2014); D. Ternary plot of $\mathrm{O}_{2}-\mathrm{N}_{2}-\mathrm{Ar}$ in silica speleothems from Furnas Cave, Gallicia, Spain. All samples are oxygen depleted (see text for details). There is an increase in nitrogen in the Distal and Middle samples, possibly attributable to nitrate breakdown (see text for discussion); E. Ternary plot of He-N2-Ar in silica speleothems from Furnas Cave. Data is quite variable. However, the large sample provides a close match for ASW; F. Ternary plot of $\mathrm{O}_{2}-\mathrm{N}_{2}-\mathrm{CH}_{4}$ in silica speleothems from Furnas Cave. All samples are more or less depleted in oxygen. There appears to be a trend of increasing methane from proximal to distal samples. 
(Fig. 3B). Preliminary dating of the same speleothem from Arroyo Azul, using sample PAA-02, which is more distal (and hence, probably younger) than the analyzed PAA-07 yielded dates of 20 - 27 ka (J.P. Bernal, unpub. results, pers. comm.). The sample had visible evidence of diagenetic reworking thus we are not presenting this datum with high confidence, however, it may potentially be indicative of approximate age of the outer portion of this speleothem.

Red Stream, Cueva de Villa Luz, Mexico - This area of the cave conjoins water from springs with radically different chemistries into a single stream. The Red Stream pebble samples are clearly depleted in oxygen (Fig. 3A) by approximately five times relative to air-saturated water. The $\mathrm{N}_{2}$ / Ar ratio for ASW is 38 (Norman \& Musgrave, 1994). However, only one crush yielded an ASW-equivalent value whereas most $\mathrm{N}_{2} / \mathrm{Ar}$ ratios approximate to atmospheric values and higher. Helium levels are moderate relative to the other samples (Fig. 3B) with the highest values from individual crushes associated with the highest $\mathrm{N}_{2} / \mathrm{Ar}$ ratios. The Red Stream Pebble sample subset 1-4 exhibits a spatially progressive decrease in water from the core traveling to the rim. In addition, there is a relative and progressive increase in both oxygen and methane from the initial speleothem growth in the center outwards to the rim, whereas the helium decreases over the same traverse. This can be seen directly in Table 1.

\section{Spain}

O Folón - The $\mathrm{CO}_{2}$ for inclusion gases hosted in the opal samples was relatively consistent. Unlike ASW, analyses were oxygen depleted by as much as an order of magnitude and $\mathrm{N}_{2} /$ Ar ratios were twice that of ASW with the spatially distal sample pieces giving $\mathrm{N}_{2}$ / Ar ratios that exceeded 100 (Fig. 3D). Methane is also elevated and is inversely correlated with oxygen (Fig. 3F).

\section{DISCUSSION}

Although the technique will need to be applied to much larger sample sizes in order to yield statistically robust results, even our initial experiments have shown trends that at least make sense within plausible chemistry and microbiology scenarios for a given setting. We detail the results in this broad interpretive context below.

Endless Cave, NM, USA - The variability in $\mathrm{N}_{2} / \mathrm{Ar}$ ratios in Endless Cave analyses may be attributable to one or more of several processes: small air bubbles becoming trapped to variable extents within fluid inclusions, or by release of nitrogen during decay of nitrogen-containing biomolecules, or even abiotic breakdown of nitrate. We attribute minor oxygen depletion to the probable respiratory breakdown of organics by trapped heterotrophic organisms thus decreasing the oxygen levels slightly. If a biological interpretation of the oxygen results is correct, then that would perhaps favor a biological process to explain the nitrogen situation, namely the breakdown of nitrogenous biomolecules.

McKittrick Hill, the location of Endless Cave, is now part of the very arid Chihuahuan Desert but was once a much more verdant area with a higher biomass primary productivity than is present today in a desert region (Dick-Peddie, 1999). Thus, at the time of apparent precipitation of the speleothem, a significantly higher dissolved organic carbon load

Table 1. Summary table of selected physical and chemical factors described in the text. The fluid inclusion gas data are weighted means of the gases normalized to the above presented six gases (thus excluding water and organics) and reported in \%.

\begin{tabular}{|c|c|c|c|c|c|c|c|c|}
\hline $\begin{array}{c}\text { Speleothem } \\
\text { source }\end{array}$ & $\begin{array}{c}\text { Sample } \\
\text { designation }\end{array}$ & Material type & He & $\mathbf{C H}_{4}$ & $\mathbf{N}_{2}$ & $\mathbf{O}_{2}$ & $\mathbf{A r}$ & $\mathrm{CO}_{2}$ \\
\hline New Mexico, USA & HC 040729-3g & Pool finger & 0.001 & 0.11 & 23.8 & 8.34 & 0.54 & 67.2 \\
\hline \multirow{2}{*}{ Endless Cave } & $\mathrm{HC} 040730-2 \mathrm{~g}$ & Pool finger & 0.002 & 0.044 & 79.5 & 17.1 & 1.14 & 2.2 \\
\hline & HC 040729-7g & Pool finger & 0.002 & 0.56 & 67.2 & 11.7 & 0.86 & 19.6 \\
\hline \multirow{6}{*}{$\begin{array}{l}\text { Mexico } \\
\text { Cueva de Villa Luz }\end{array}$} & 1 & Pebble & 0.005 & 4.23 & 39.7 & 2.21 & 0.47 & 53.3 \\
\hline & 2 & Pebble & 0.004 & 2.04 & 23.5 & 1.10 & 0.28 & 73.0 \\
\hline & 3 & Pebble & 0.004 & 1.18 & 35.8 & 1.42 & 0.41 & 61.1 \\
\hline & 4 & Pebble & 0.018 & 1.34 & 14.7 & 0.52 & 0.12 & 83.3 \\
\hline & 5 & Pebble & 0.044 & 3.34 & 39.5 & 0.62 & 0.29 & 56.2 \\
\hline & 6 & Pebble & 0.001 & 1.16 & 78.2 & 6.09 & 1.24 & 13.3 \\
\hline \multirow[t]{4}{*}{ Arroyo Azul Cave } & PAA-07 (1) & Stalagmite & 0.69 & 2.46 & 16.8 & 19.5 & 0.46 & 60.0 \\
\hline & PAA-07 (2) & Stalagmite & 1.38 & 4.52 & 11.8 & 27.3 & 0.52 & 54.5 \\
\hline & PAA-07 (3) & Stalagmite & 3.65 & 8.32 & 17.4 & 34.8 & 0.95 & 34.9 \\
\hline & PAA-07 (4) & Stalagmite & 1.50 & 5.66 & 23.7 & 27.6 & 0.73 & 40.8 \\
\hline \multirow{4}{*}{$\begin{array}{l}\text { Spain } \\
\text { O Folón Cave }\end{array}$} & Large & Small stalagmite & 0.002 & 1.34 & 76.1 & 2.54 & 0.94 & 19.1 \\
\hline & Proximal & & 0.003 & 2.51 & 47.1 & 0.59 & 0.63 & 49.2 \\
\hline & Middle & & 0.002 & 7.32 & 42.3 & 0.14 & 0.26 & 50.0 \\
\hline & Distal & & 0.002 & 4.70 & 41.9 & 0.45 & 0.38 & 52.6 \\
\hline
\end{tabular}


was undoubtedly present in the infiltrating surface waters. The single age date of $\sim 0.5 \mathrm{Ma}$ cited in the results (Polyak, pers. comm., 2013) constrains the time period of interest to at least a limited extent placing it significantly before the end Pleistocene climatic events.

Arroyo Azul Cave, Poana, Tabasco, Mexico PAA-07 data shown in Fig. 3A exhibit an oxygen enrichment to the left bottom corner of the $\mathrm{O}_{2}-\mathrm{N}_{2}$-Ar ternary diagram. Such a result is obviously only achieved if oxygen is increasing. The most plausible explanation is the generation of oxygen within the inclusion. However, in a dark cave we cannot expect photosynthesis to occur directly within the cave itself. It is possible that the fluid entering the cave at time of inclusion entrapment was enriched with oxygen, possibly from a stream or other source at the surface where photosynthetic organisms might have been producing high levels of oxygen. This area is currently heavily vegetated tropical forest and has been proposed to form part of a tropical high rainfall regime from Pleistocene time (2.5 Ma) (Wendt, 1987; Salazar-Conde et al., 2004; INEGI, 2005). Alternatively, we consider the possibility that chlorine gas associated with the nearby volcano might oxidize water to produce oxygen by the following reaction:

$$
2 \mathrm{H}_{2} \mathrm{O}+2 \mathrm{Cl}_{2}=4 \mathrm{HCl}+\mathrm{O}_{2}
$$

However, any decay process of organic matter trapped in inclusions would actually depress oxygen as it was used to mineralize the organic carbon back to $\mathrm{CO}_{2}$ rather than enrich it. Another alternative explanation for oxygen elevation could be the breakdown of oxyhydroxides during the formation of red hematite staining, as has been seen in other instances where oxygen exceeds ASW values (McMahon et al., 2012). There is definitely red hematite present in this cave, coating a number of speleothems and being incorporated as visually detectable banding in some specimens (Spilde \& Boston, 2010, 2014 unpub. results).

Red Stream, Cueva de Villa Luz, Mexico - Red Stream Pebbles exhibit strong oxygen depletion. The Red Stream Pebbles occur at the confluence of slow moving shallow streams of low oxygen content, and the cave's atmosphere which also has measurably low oxygen at that locality (Hose et al., 2000; Rosales-Lagarde, 2012) thus matching the fluid inclusion data but not precisely proportionately. We know on the basis of prior work, that sulfide-rich, anaerobic waters mix with oxygen-rich, non-sulfide waters in the entire regional and cave hydrological systems (Rosales-Lagarde et al., 2007, 2008, 2012). The oxygen levels in the Red Stream part of the cave can range as low as $14 \%$ in the air, while elsewhere in the cave $\mathrm{O}_{2}$ levels as low as $9.6 \%$ have been recorded (Boston, unpub. res.), and $0.1 \mathrm{mg} / 1$ in the water (Hose et al., 2000) although it can be as high as $5.7 \mathrm{mg} / 1$ (saturation at typical surface conditions is $\sim 9.1 \mathrm{mg} / 1$; Rosales-Lagarde et al., 2007, 2008). Unlike the previously described samples, the Red Stream
Pebble sample has highly variable $\mathrm{N}_{2} /$ Ar ratios with some analyses exhibiting $\mathrm{N}_{2}$ / Ar ratios that are greater than atmosphere. One might expect a limit of 83.6 for $\mathrm{N}_{2}$ / Ar ratios thus matching the atmosphere but we consider two alternatives as potential explanations for these data.

Firstly, nitrate reduction is a potential process that would generate diatomic nitrogen. Nitrate reduction can be expressed by a chemical reaction in which nitrate consumes acid in an oxygen-poor environment to produce nitrogen:

$$
2 \mathrm{NO}_{3}{ }^{-}+12 \mathrm{H}^{+}+10 e^{-}=\mathrm{N}_{2}+6 \mathrm{H}_{2} \mathrm{O}
$$

An acid and a reducing environment will drive this reaction to the right by Le Chatelier's principle (Krauskopf \& Bird, 1994). The Red Stream environment is known to have high concentrations of sulfuric acid the magnitude of which varies on a continuous basis, and it is very oxygen poor (Malaska \& Kelly, 2014 unpub. results). Thus, we consider nitrate reduction as a plausible mechanism whereby, within an oxygen-poor environment, fluids may become enriched in nitrogen.

The second alternative hypothesis is that influx of condensing magmatic volatiles from El Chichón Volcano $(\sim 30 \mathrm{~km}$ distant) are responsible for the gases associated with the Red Stream. Volcanic gases are expected to be rich in sulfur species and the Red Stream contains significant dissolved sulfuric acid from both aqueous reactions in the stream itself and from wall rock interactions of thin fluid films with $\mathrm{H}_{2} \mathrm{~S}$ emitted from numerous springs (Hose et al., 2000; Spilde et al., 2004; Rosales-Lagarde, 2012). In addition, the stream is strongly oxygen depleted which matches volcanic gas composition. A definite correlation of gases within the cave with gas data from the El Chichón Volcano (Spilde et al., 2004) has shown that there must be some physical connection between the two geological features (Rosales Lagarde et al 2007, 2008) and thus we suggest that volcanic gases are plausibly involved in the fluid inclusion results shown here. Finally, magmatic gases typically have high $\mathrm{N}_{2}$ / Ar ratios (Norman \& Musgrave, 1994; Blamey, 2012) and the analyses of the Red Stream samples have $\mathrm{N}_{2} / \mathrm{Ar}$ ratios that exceed 100. Fluctuating contributions of atmosphere and volcanic volatiles can explain the spread within the data.

Curiously, helium levels are variable (Fig. 3B). We know that a balance exists in our atmosphere between helium being lost to space versus helium that is produced within the crust. Such variability is uncommon in geological systems where helium levels are generally in the ppm range. Whereas most speleothem samples are within one order of magnitude higher in helium than atmosphere, both the Red Stream pebbles and PAA-07 have abnormally elevated helium. Close proximity to a volcano might explain the elevated helium in the Red Stream pebbles because of the demonstrated relationship to El Chichón Volcano (Spilde et al., 2004), but PAA-07 has no obvious volcanic connection. Although difficult to prove, a much longer flow path could conceivably explain the 
elevated helium from deeper sources (Norman and Musgrave, 1994). However, determining the length of such a flow path in a hydrologically intermittent environment where dye tracing is not possible is a tricky calculation and poorly constrained.

Interestingly, the six sample time-series subset collected from the Red Stream pebble confirms a progressive change in fluid inclusion gas chemistry through time. The increase in oxygen and decreasing helium may be explained by changing contributions at the confluence of the anaerobic and the aerobic streams such that flow from the anaerobic stream has relatively decreased. The progressive change in methane may well reflect biological activity (either methane production by methanogens, or consumption by methanotrophs) but this avenue of research needs significant refinement before any interpretation can be made. However, the change in gas chemistry with distance from inside to outside layers of the specimen does confirm that in principle, we can distinguish such changes in speleothem inclusions through time. It also confirms that analyzing dissolved fluid inclusion gases offers a means to record changing environmental conditions within a cave system and potentially compare cave systems to one another. The potential for microbial processes to interfere with such environmental and climatic interpretations has been largely ignored so far.

\section{Granite Caves}

Figure $3 \mathrm{E}$ shows moderately elevated helium in several of the granite cave samples. We believe it unlikely that residence time is relevant here, however, as early as 1950, emissions of alpha particles from granites were shown to be higher than expected based solely on uranium and thorium content because of the emitting effects of high surface area (Hurley, 1950). The medium to coarse-grained granites comprising the Spanish cave provide a great deal of surface area which would be consistent with some elevated helium results. In Fig. 3F, the variation in $\mathrm{CH}_{4}$ proportion relative to $\mathrm{N}_{2}$ and $\mathrm{O}_{2}$ may be related to different amounts of organic matter when particular fluid inclusions where trapped. The heavy lichen coating on the granite surface outcrops above the cave, and the forested surface setting produce significant surface biomass and this is a plausible external source of organic carbon. This is significant in this environment because the granite itself does not possess any intrinsic organic content to help support methanogenesis as might be the case in some other lithologies, namely carbonates, which often do contain organics that were incorporated at the time of deposition (Wald et al., 2012; Thauer, 1998). As everyone appreciates, the common conception ofmethanogenesis involves strictly anaerobic conditions (e.g., Houghton et al., 2001), however, the controversial notion of aerobic methanogenesis has been reported at least for plants (Keppler et al., 2006). Perhaps more importantly, the presence of anaerobic microsites in soils with overall bulk conditions, or in proximity to aerobic microsites has been documented in a variety of settings (e.g., Verchot et al., 2000; Li et al., 2000). Either of those circumstances, could result in elevated methane in some inclusions dependent upon highly local and possibly very transient circumstances. When oxygen was also present in the system, then the methane would subsequently react and draw down the oxygen. The scale at which such competing redox processes could operate vis a vis the scale of the inclusions themselves is unknown at this point, although once again we emphasize that it is well known that in soils there is the simultaneous presence of aerobic and anaerobic microsites (e.g., Tiedje et al., 1982). Although methanogens are notoriously oxygen sensitive in the common wisdom, it has been shown that this is not always the case (e.g., Kiener \& Leisinger, 1983; Mayer \& Conrad, 1990; Fetzer \& Conrad, 1993; Fetzer et al., 1993; Ueki et al., 1997).

\section{Relative Merits of Normalizers}

The presence of dissolved argon in all specimens is an excellent way to normalize the data to gas values dissolved in air-saturated water (ASW), as a basis for comparison of potential biologically produced gases. Many of the dissolved gaseous species vary in composition and tracking changes is complicated. The abundance of oxygen and nitrogen may be controlled by biological processes, and tracking these increases or decreases requires a gas specie that remains unaffected. For this reason we utilize argon, as its abundance is well within the detection of the mass spectrometer system and it is neither added to nor removed by biological activity. The only way to increase the argon concentration is by proximity to K-bearing minerals (McDougall \& Harrison, 1988) that are subjected to thermal conditions above the closure temperature of the mineral that is highly unlikely in speleothems. This type of process is restricted to high temperature metamorphic environments and is negligible compared to the relatively large concentration of argon in ASW. We therefore consider that tracking gases relative to argon is a viable means to monitor changes of nitrogen, oxygen and methane.

Helium is also a noble gas with trace quantities in the atmosphere and very low abundances in ASW, thus it could also be considered to play a similar role to argon. However, helium may increase due to several radioactive sources within the crust, thus it is less desirable as a normalization species because of this non-exclusivity of origin.

\section{CONCLUSIONS}

We have confirmed that speleothem fluid inclusion gas compositions are not homogeneous. Changes in fluid chemistry trapped within speleothem materials are measurable as is demonstrated by our analyses of a variety of speleothem types occurring in a variety of different geochemical and lithological cave settings. In some cases, oxygen levels within inclusions were enriched above air-saturated water levels and in contrast, other samples showed oxygen depletion. High nitrogen in the Red Stream samples indicates either breakdown of nitrogenous organic matter or nitrate to produce excess nitrogen, or it may confirm an influx 
of volcanic volatiles from a nearby volcanic source. We have demonstrated the plausibility of using dissolved fluid inclusion gas analyses as a possible avenue to help understand paleoenvironmental conditions in cave systems at the time of fluid inclusion formation in speleothems. We have pointed out that there are several alternative explanations for each of our preliminary results involving a mixture of chemical and biological processes and conclude that our methodology will need to be employed on larger sample suites, perhaps with the addition of other techniques to sort out the many potential influences on inclusion contents. Besides the intrinsic value of understanding paleoenvironmental cave conditions, and residual microbial activity once trapped in inclusions, the emphasis on speleothems as paleoclimate proxies make the identification of any confounding microbial or geochemical fluid inclusion processes important to understand to help with interpretation of that type of climate data.

\section{ACKNOWLEDGMENTS}

We thank Mr. Jim Goodbar and his agency the Bureau of Land Management (State of New Mexico) for granting permission to access Endless Cave to conduct sample collection and research. We are grateful to the Municipality of Tapijulapa, Tabasco, Mexico for access to Cueva de Villa Luz and Arroyo Azul Cave. We are grateful to our friend and colleague Dr. JuanRamon Vidal Romani, of the Instituto Universitario de Geologia, Universidad de Coruña, Gallicia, Spain for introducing us to the magnificent granite caves of northern Spain and Portugal and providing his insight into the processes underway there. We thank Juan Pablo Bernal of Centro de Geociencias, UNAM, Mexico City, Mexico for informally sharing his dating estimate of a speleothem in close proximity to the Poana speleothem that we analyzed. We are also grateful to Dr. Victor Polyak, of the Earth and Planetary Sciences Department, University of New Mexico, Albuquerque, New Mexico for informally sharing his age date of a speleothem from Endless Cave, NM.

\section{REFERENCES}

Abraini J.H., Rostain J.C. \& Kriem B., 1998 - Sigmoidal compression rate-dependence of inert gas narcotic potency in rats: Implication for lipid vs protein theories of inert gas action in the central nervous system. Brain Research, 808 (2): 300-304.

http://dx.doi.org/10.1016/S0006-8993(98)00760-4

Arneth A., Sitch S., Bondeau A., Butterbach-Bahl K., Foster P., Gedney N., de Noblet-Ducoudré N., Prentice I.C., Sanderson M., Thonicke K., Wania R. \& Zaehle S., 2010 - From biota to chemistry and climate: towards a comprehensive description of trace gas exchange between the biosphere and atmosphere. Biogeoscience, 7: 121-149.

http://dx.doi.org/10.5194/bg-7-121-2010

Azmy K. \& Blamey N.J.F., 2013 - Source of diagenetic fluids from fluid-inclusion gas ratios. Chemical Geology, 347: 246-254.

http://dx.doi.org/10.1016/j.chemgeo.2013.04.011
Baudin F., Combourieu-Nebout N. \& Zahn R., 2007 Signatures of rapid climate changes in organic matter records in the western Mediterranean Sea during the last glacial period. Bulletin de la Sociéte Géologique de France, 178: 3-10. http://dx.doi.org/10.2113/gssgfbull.178.1.3

Blamey N.J.F., 2012 - Composition and evolution of crustal, geothermal and hydrothermal fluids interpreted using quantitative fluid inclusion gas analysis. Journal of Geochemical Exploration, 116-117: 17-27.

http://dx.doi.org/10.1016/j.gexplo.2012.03.001

Blamey N.J.F. \& Norman D.I., 2002 - New interpretations of geothermal volatiles: $\mathrm{Ar} / \mathrm{He}$ and $\mathrm{N}_{2} / \mathrm{Ar}$ ratios better indicator of magmatic volatiles, and equilibrium gas geothermometry. In: Proceedings, 27 ${ }^{\text {th }}$ Workshop of Geothermal Reservoir Engineering, Stanford University, Stanford, California, January 28-30, CD.

Blamey N.J.F., Parnell J. \& Longerich H.P., 2012 - Understanding detection limits in fluid inclusion analysis using an incremental crush fast scan method for planetary science. LPSC, abstract 1035.

Blamey N.J.F., Parnell J., McMahon S., Mark D., Tomkinson T., Lee M., Shivak J., Izawa M.R.M., Banerjee N.R. \& Flemming R.L., 2015 - Evidence for methane in Martian meteorites. Nature Communications. 6: 7399 http://dx.doi.org/10.1038/ncomms8399

Boston P.J., Hose L.D., Northup D.E. \& Spilde M.N., 2006 - The microbial communities of sulfur caves: A newly appreciated geologically driven system on Earth and potential model for Mars. In: Harmon R. (Ed.), Karst geomorphology, hydrology, and geochemistry: Geological Society of America Special Paper 404, 331-344.

http://dx.doi.org/10.1130/2006.2404(28)

Boston P.J., Spilde M.N., Northup D.E., Curry M.C., Melim L.A. \& Rosales-Lagarde L., 2009 - Microorganisms as speleogenetic agents: Geochemical diversity but geomicrobial unity. In: Klimchouk A.B. and Ford D.C. (Eds.), Hypogene Speleogenesis \& Karst Hydrology of Artesian Basins, Special Paper 1, 51-57.

Boston P.J., Spilde M.N., Northup D.E., Melim L.A., Soroka D.S., Kleina L.G., Lavoie K.H., Hose L.D., Mallory L.M., Dahm C.N., Crossey L.J. \& Schelble R.T., 2001 - Cave biosignature suites: Microbes, minerals and Mars. Astrobiology Journal, 1 (1): 25-55. http://dx.doi.org/10.1089/153110701750137413

Brook G.A., Elwood B.B., Railsback L.B. \& Cowart J.B., 2006 - A 164 ka record of environmental change in the American Southwest from a Carlsbad Cavern speleothem. Palaeogeography, Palaeoclimatology, Palaeoecology, 237: 483-507. http://dx.doi.org/10.1016/j.palaeo.2006.01.001

Curry M., Boston P.J., Spilde M.N., Baichtal J. \& Campbell A., 2009 - Cottonballs: A unique subaqueous moonmilk, and abundant subaerial moonmilk in Cataract Cave, Tongass National Forest, Alaska. International Journal of Speleology, 38 (2): 111-128.

http://dx.doi.org/10.5038/1827-806X.38.2.3

Dennis P.F., Rowe P.J. \& Atkinson T.C., 2001 - The recovery and isotopic measurement of water from fluid inclusions in speleothems. Geochimica et Cosmochimica Acta, 65: 871-884.

Dick-Peddie W.A., 1999 - New Mexico Vegetation: Past, Present, and Future. University of New Mexico Press, Albuquerque, NM.

Dublyansky Y.V. \& Spotl C., 2009 - Hydrogen and oxygen isotopes of water from fluid inclusions in minerals: design of a new crushing system and online continuousflow isotope ratio mass spectrometric analysis. Rapid Communications in Mass Spectrometry, 23: 2605-2613. http://dx.doi.org/10.1002/rcm.4155 
Fetzer, S. \& Conrad R., 1993 - Effect of redox potential on methanogenesis by Methanosarcina barkeri. Archives of Microbiology, 160: 108-113.

http://dx.doi.org/10.1007/BF00288711

Fetzer S., Bak F. \& Conrad R., 1993 - Sensitivity of methanogenic bacteria from paddy soil to oxygen and dessication. FEMS Microbiology \& Ecology, 12: 107-115. http://dx.doi.org/10.1111/j.1574-6941.1993. tb00022.x

Fleitmann D., Burns S.J., Neff U., Mangini A. \& Matter A., 2003 - Changing moisture sources over the last 330,000 years in Northern Oman from fluid inclusion evidence in speleothems. Quaternary Research, 60: 223-232. http://dx.doi.org/10.1016/S0033-5894(03)00086-3

Genty D., Plagnes V., Causse C., Cattani O., Stievenard M., Falourd S., Blamart D., Ouahdi R. \& Van-Exter S., 2002 - Fossil water in large stalagmite voids as a tool for palaeoprecipitation stable isotope composition reconstitution and palaeotemperature calculation. Chemical Geology, 184: 83-95. http://dx.doi.org/10.1016/S0009-2541(01)00356-4

Hill C.A. \& Forti P., 1997 - Cave minerals of the world (2 ${ }^{\text {nd }}$ ed.). National Speleoleological Society, Huntsville, AL, 463 p.

Hose L.D., Palmer A.N., Palmer M.V., Northup D.E., Boston P.J. \& Duchene H.R., 2000 - Microbiology and geochemistry in a hydrogen sulphide-rich karst environment. Chemical Geology, 169: 399-423. http://dx.doi.org/10.1016/S0009-2541(00)00217-5

Houghton J.T., Ding Y., Griggs D.J., Noguer M., van der Linden P.J., Dai X., Maskell K. \& Johnson C.A., (Eds.), 2001 - Climate change 2001: the scientific basis. Cambridge Univ. Press, Cambridge, UK. 890 p.

IINEGI (Instituto Nacionl de Estadística, Geografia e Informática), 2005 - Carta Topográfica 1:50,000, Teapa E15D21 (3a ed.), http://www3.inegi.org.mx/sistemas/ biblioteca $/$ detalle 2 . aspx?c $=2031 \& u p c=0 \& s=g e o \& t g=9$ 99\&f $=2 \& \mathrm{cl}=0 \& \mathrm{pf}=$ prod $\& \mathrm{ef}=0 \& \mathrm{ct}=206000000$

Keppler F., Hamilton J.T.G., Brass M. \& Rockmann T., 2006 - Methane emissions from terrestrial plants under aerobic conditions. Nature, 439: 187-191. http://dx.doi.org/10.1038/nature04420

Kiener A. \& Leisinger T., 1983 - Oxygen sensitivity of methanogenic bacteri. Systematic Applied Microbiology, 4: 305-312.

http://dx.doi.org/10.1016/S0723-2020(83)80017-4

Kluge T., Marx T., Scholz D., Niggermann S., Mangini A. \& Aeschbach-Hertig W., 2008 - A new tool for palaeoclimate reconstruction: Noble gas temperatures from fluid inclusions in speleothems. Earth and Planetary Science Letters, 269: 408-415.

http://dx.doi.org/10.1016/j.epsl.2008.02.030

Krauskopf K.B. \& Bird D.K., 1994 - Introduction to geochemistry ( $3^{\text {rd }}$ ed.). McGraw-Hill Science and Engineering.

Li C.S., Aber J., Stange F., Butterbach-Bahl K. \& Papen H., 2000 - A process-oriented model of $\mathrm{N}_{2} \mathrm{O}$ and $\mathrm{NO}$ emissions from forest soils: 1. Model development. Journal of Geophysical Research, Atmospheres, 105 (D4): 4369-4384.

Matthews A., Ayalon A. \& Bar-Matthews M., 2000 $D / H$ ratios of fluid inclusions of Soreq cave (Israel) speleothems as a guide to the Eastern Mediterranean Meteoric Line relationships in the last $120 \mathrm{ky}$. Chemical Geology, 166: 183-191.

Mayer H.P. \& Conrad R., 1990 - Factors influencing the population of methanogenic bacteria and the initiation of methane production upon flooding of paddy soil. FEMS Microbiology \& Ecology, 73: 103-112.

http://dx.doi.org/10.1111/j.1574-6968.1990.tb03930.x
McDermott F., 2004 - Palaeo-climate reconstruction from stable isotope variations in speleothems: a review. Quaternary Science Reviews, 23: 901-918.

http://dx.doi.org/10.1016/j.quascirev.2003.06.021

McDougal I. \& Harrison T.M., 1988 - Geochronology and thermochronology by the ${ }^{40} \mathrm{Ar} /{ }^{39} \mathrm{Ar}$ method. Oxford University Press, New York. 212 pp.

McGarry S., Bar-Matthews M., Matthews A., Vaks A., Schilman B. \& Ayalon A., 2004 - Constraints on hydrological and paleotemperature variations in the Eastern Mediterranean region in the last 140ka given by the $\mathrm{SD}$ values of speleothem fluid inclusions. Quaternary Science Reviews, 23: 919-934.

http://dx.doi.org/10.1016/j.quascirev.2003.06.020

McMahon S., Parnell J. \& Blamey N.J.F., 2012 - Sampling methane in hydrothermal minerals on Earth and Mars. International Journal of Astrobiology, 11: 163-167. http://dx.doi.org/10.1017/S1473550412000067

McMahon S., Parnell J. \& Blamey N.J.F., 2013 - Sampling methane in basalt on Earth and Mars. International Journal of Astrobiology. 12 (2): 113-122. http://dx.doi.org/10.1017/S1473550412000481

Melim L.A., Liescheidt R., Northup D.E., Spilde M.N., Boston P.J. \& Queen J.M., 2009 - A bio-signature suite from cave pool precipitates, Cottonwood Cave, New Mexico. Astrobiology, 9: 907-917.

http://dx.doi.org/10.1089/ast.2009.0345

Melim L.A., Shinglman K.M., Boston P.J., Northup D.E., Spilde M.N. \& Queen J.M., 2001 - Evidence of microbial involvement in pool finger precipitation, Hidden Cave, New Mexico. Geomicrobiology Journal, 18: 311-330.

http://dx.doi.org/10.1080/01490450152467813

Nordt L.C., Hallmark C.T., Driese S.G., Dworkin S.I. \& Atchley S.C., 2012 - Biogeochemical characterization of a lithified paleosol: Implications for the interpretation of ancient Critical Zones. Geochimica et Cosmochimica Acta, 87: 267-282.

http://dx.doi.org/10.1016/j.gca.2012.03.019

Norman D.I. \& Blamey N.J.F., 2001 - Quantitative gas analysis of fluid inclusion volatiles by a two mass spectrometer system. European Current Research on Fluid Inclusions, XVI, Porto, Portugal, Abstracts, p. 341-344.

Norman D.I. \& Moore J.N., 1997 - Gaseous species in fluid inclusions: a fluid tracer and indicator of fluid processes. European Current Research on Fluid Inclusions, XIV, Nancy, France, Abstracts, p. 243-244.

Norman D.I. \& Musgrave J.A., 1994 - $N_{2}$-Ar-He compositions in fluid inclusions: Indicators of fluid source. Geochimica et Cosmochimica Acta, 58: 11191131. http://dx.doi.org/10.1016/0016-7037(94)90576-2

NSF (National Science Foundation) 2011 - NSF Critical Zone Observatory Program: Panel Report, April 4, 2011. Palmer A.N., 2007 - Cave Geology. Cave Books, 454 p.

Parnell J., Bowden S.A., Muirhead D., Blamey N.J.F., Westall F., Demets R., Verchovsky S., Brandstätter F. $\&$ Brack A., 2011 - Preservation of organic matter in the STONE 6 artificial meteorite experiment. Icarus, 212: 390-402.

http://dx.doi.org/10.1016/j.icarus.2010.11.029

Roedder E., 1984 - Fluid inclusions. Mineralogical Society of America. Reviews in Mineralogy, 12: 644 p.

Rosales-Lagarde L. 2012 - Investigation of karst brackishsulfidic springs and their role in the hydrogeology, subsurface water-rock interactions, and speleogenesis at northern Sierra de Chiapas, Mexico. PhD Dissertation, New Mexico Institute of Mining \& Technology, Socorro, NM. 
Rosales-Lagarde L., Boston P.J., Pullin M. \& Stafford K.W., 2007 - Exploración de la extension de la espeleogénesis por ácido sulfúrico en la región norte de Chiapas, sur de Tabasco, México. VIII Congreso Nacional Mexicano de Espeleología, Unión Mexicana de Agrupaciones Espeleológicas, Cuetzalan, Puebla, 2-5 Febrero, Memorias, 65-66.

Rosales-Lagarde L., Boston P.J., Campbell A, Hose L, Axen G. \& Stafford K., 2014 - Hydrogeology of northern Sierra de Chiapas, Mexico: A conceptual model based on a geochemical characterization of sulfide-rich karst brackish springs. Hydrogeology Journal, 22 (6): 1447-1467.

http://dx.doi.org/10.1007/s10040-014-1135-Z

Rosales-Lagarde L., Boston P.J., Campbell A. \& Stafford K.W., 2008 - Possible structural connection between Chichón Volcano and the sulfur-rich springs of Villa Luz Cave (a.k.a. Cueva de las Sardinas), southern Mexico. Bulletin of the Association of Mexican Cave Studies (Austin, TX), 19: 177-184.

Salazar-Conde E. dC., Zavala Cruz J., Castillo Acosta O. \& Cámara Artigas R., 2004 - Evaluación espacial y temporal de la vegetación de la Sierra Madrigal, Tabasco, México (1973-2003). Investigaciones Geog'raficas. Boletín del Instituto de Geografia, UNAM 54: 7-23.

Scheidegger Y., Baur H., Brennwald M.S., Fleitmann D., Wieler R. \& Kipfer R., 2010 - Accurate analysis of noble gas concentrations in small water samples and its application to fluid inclusion in stalagmites. Chemical Geology, 272: 31-39.

http://dx.doi.org/10.1016/j.chemgeo.2010.01.010

Schwarcz H.P., Harmon R.S. \& Thompson P., 1976 Stable isotope studies of fluid inclusions in speleothems and their paleoclimatic significance. Geochimica et Cosmochimica Acta, 40: 657-665. http://dx.doi.org/10.1016/0016-7037(76)90111-3

Serefiddin F., Schwarcz H.P. \& Ford D.C., 2005 - Use of hydrogen isotope variations in speleothem fluid inclusions as an independent measure of paleoclimate. In: Mora G. \& Surge D. (Eds.), Isotopic and elemental tracers of Cenozoic climate change, Volume 392: Geological Society of America Special Papers: Boulder, $\mathrm{CO}$, Geological Society of America.

http://dx.doi.org/10.1130/0-8137-2395-7.43

Spilde M.N., Fischer T.P., Northup D.E., Turin H.J., \& Boston P.J., 2004 - Water, gas, and phylogenetic analyses from sulfur springs in Cueva de Villa Luz, Tabasco, Mexico. Geological Society of America Abstracts with Programs, vol. 36, Abstr. \#106-11.

Thauer R.K., 1998 - Biochemistry of methanogenesis: a tritbute to Marjory Stephenson, Microbiology, 144: 2377-2406.

http:/ / dx.doi.org/10.1099/00221287-144-9-2377
Tiedje J.M., Sexstone A.J., Myrold D.D. \& Robinson, J.A., 1982 - Denitrification: Ecological niches, competition and survival. Antonie van Leeuwenhoek 48:569-583 http://dx.doi.org/10.1007/BF00399542

Ueki A., Ono K., Tsuchiya A. \& Ueki K., 1997 - Survival of methanogens in air-dried paddy field soil and their heat tolerance. Water Science \& Technology 36: 517-522. http://dx.doi.org/10.1016/S0273-1223(97)00563-5 van Breukelen M.R., Vonhof H.B., Hellstrom J.C., Wester W.C.G. \& Kroon D., 2008 - Fossil dripwater in stalagmites reveals Holocene temperature and rainfall variation in Amazonia. Earth and Planetary Science Letters, 275: 54-60.

http://dx.doi.org/10.1016/j.eps1.2008.07.060

Verchot L.V., Davidson E.A., Cattanio J.H. \& Ackerman I.L., 2000 - Land-use change and biogeochemical controls of methane fluxes in soils of eastern Amazonia. Ecosystems, 3 (1)Hydrology 41-56. http://dx.doi.org/10.1007/s100210000009

Verheyden S., Genty D., Cattani O. \& van Breukelen M.R., 2008 - Water release patterns of heated speleothem calcite and hydrogen isotope composition of fluid inclusions. Chemical Geology, 247: 266-281. http://dx.doi.org/10.1016/j.chemgeo.2007.10.019

Vidal-Romaní J.R. \& Vaquiero-Rodriguez M., 2007 Types of granite cavities and associated speleothems: Genesis and evolution. Nature Conservation, 63: 41-46.

Vidal-Romaní J.R., Sanjurjo-Sánchez J., Vaqueiro-Rodriguez M. \& Fernández-Mosquera D., 2010a - Speleothems of granite caves. Comunicações Geológicas, 97: 71-80.

Vidal-Romaní J.R., Sanjurjo-Sánchez J., VaqueiroRodriguez M. \& Fernández-Mosquera D., 2010b - Speleothem development and biological activity in granite caves. Geomorphologie: Relief, Processes, Environment, 4: 337-346.

Wald J.A., Graham R.C. \& Schoeneberger P.J., 2012 Distribution and properties of soft weathered bedrock at $\leq 1 \mathrm{~m}$ depth in the contiguous United States. USDA-ARS/ UNL Faculty. Paper 1131. http://digitalcommons.unl. edu/usdaarsfacpub/1131 Digital Commons [accessed: August 3, 2016].

Wendt T., 1987 - Las selvas de Uxpanapa, VeracruzOaxaca, México, evidencia de refugios florísticos Cenozoicos. Anales del Instituto de Biología serie Botánica, 58, UNAM, México, 29-54.

Wong C.I. \& Breecker D.O., 2015 - Advancements in the use of speleothems as climate archives. Quaternary Science Reviews 127: 1-18.

Wright A.J., Blamey N.J.F., Conliffe F.J. \& Parnell J., 2012 - Origin of vein-graphite in Moine (Glenfinnan Group) rocks, NW Scotland, supported by the study of volatile gases in fluid-inclusions. Scottish Journal of Geology, 48: 47-59. http://dx.doi.org/10.1144/0036-9276/01-426 